\title{
The Workers May Yet Unite: Media Misdirection Versus The Political and Cultural Economy of the US Auto Industry and Worker Attitudes
}

\author{
George N. Lundskow, Brian Phillips, Phyllis Curtiss, Katherine Rehorst, Allison M. Wehr
}

\section{Introduction}

The recent controversy in November and December of 2008 which resurfaced in February 2009 over bridge loans to sustain the US auto industry through a declining market has been framed in two basic ways, and sometimes together: 1) That the Detroit Three companies (General Motors, Ford, and Chrysler) do not build cars that people want to buy, and 2) that bad management in conjunction with an unreasonable union has made them unprofitable, now and in the future. Both arguments lack factual veracity, and just as importantly, this media misdirection conceals larger issues of global capital and class struggle behind the battle over bridge loans to the Detroit Three.

Allegedly, people do not want to buy US cars because of poor quality and undesirable features. In reality, market share during the period of greatest public controversy was: GM with 22.3\%, Toyota 16.7, Ford 15.0, Chrysler 11.0, Honda 10.8, Nissan 7.2, and Hyundai 3.0 (Tierney, Snell, and Hoffman 2009). The fisrt quarter sales report from GM (McDonald 2009) showed that key new models were all up over the previous year for an increase of $23 \%$ in retail car sales and a $6 \%$ increase in crossover sales. GM total sales were down $51 \%$ as a result of a $75 \%$ decline in fleet sales, although restricting fleet sales was mostly intentional. In contrast, Toyota retail car sales declined by $31.7 \%$ in the same period (Iliffe-Moon and Zeigler 2009), and Honda car sales declined by 35.4\% (Honda Press Release 2009). In 2008 , Ford actually improved its market share by .7\%, even as the overall market declined by nearly $20 \%$ (Snavely 2009). This downturn prompted Toyota to ask the Japanese government for $\$ 2$ billion for its financial unit (Walsh 2009) which ran out of cash at the end of the year.

Regarding quality, the industry standard Harbour Report North America (2008) concludes, as well as various car magazines and the problematic but influential (see Karesh 2007, 2006; Lundskow 2008) Consumer Reports (Editors 2008), that the Detroit Three have reached parity in many segments and lead in some.

Like their employers, the United Auto Workers (UAW) face harsh attacks from a Congressional contingent led by Senators Richard Shelby and Jeff Sessions of Alabama and Mitch McConnell of Kentucky (Spangler 2008), as well as Senator Bob Corker of Tennessee and University of Maryland professor Peter Morici (2008). Representing the Southern corridor of non-union Japanese, German, and Korean facilities located in Alabama, Kentucky, Tennessee, South Carolina, and Mississippi, they added mandates to President Bush's bridge loans in December 2008 that required GM and Chrysler to reduce employee and retiree healthcare and retirement benefits by half, and wages by $25 \%$ beyond the reduction in the new contract agreement that would have started in 2009 (Merx 2008). It also prohibited the UAW from striking, else the immediate recall of all loans (Hyde and Higgins 2009). Now in effect after the bankruptcy proceedings these reductions and prohibitions match the wages, benefits, and terms of their non-union counterparts in the Southern corridor. Although President Obama's auto task force maintained these 
requirements as Chrysler and GM went through bankruptcy in May through July of 2009, the UAW health and retirement fund now holds $17.5 \%$ of GM and 55\% of Chrysler (Snell 2009).

Central to the justification for these reductions in wages and benefits, Senator Corker argued that North American unions use collective bargaining to maintain lax work rules, which protects inefficiency (Maynard 2008). In fact, the aformentioned Harbour Report (2008), which assesses productivity in four areas—assembly, stamping, engine, and transmission-ranks Detroit Three union assembly plants as the top ten most productive, with no statistically significant difference in terms of quality. By comparison, Toyota's North American assembly operations among their five plants actually increased in total labor hours per vehicle from 22.05 in 2006 to 22.35 in 2007.[i] While the report shows that Toyota maintains a slight lead in overall productivity, this results from their greater efficiency among union workers in Japan, where Toyota produces most of its parts and nearly all of its transmissions. No non-US company currently produces transmissions in North America (United States, Canada, Mexico).

Similarly, academic literature often portrays union workers negatively, but in a different way. According to some, unions are insensitive, if not hostile, to immigrant labor and their potential for unionization (Apostolidis 2005; Chang 2003). Although the SEIU (Service Employees International Union) has organized immigrant labor over the last two decades, some industrial unions, notably the International Brotherhood of Teamsters under James Hoffa Jr., have indeed steered their membership toward anti-immigrant candidates (Aronowitz 1998; Francia 2006). This has led some to conclude that a corresponding anti-immigrant, xenophobic attitude likely exists among industrial union workers generally (Lüthje and Scherrer 2001; Preston, McLafferty, and Liu 1998). The literature also suggests a connection between unionized labor and ethnocentric notions of American identity, as for example in Battista (2008) and Loewen (2007), but these studies treat all union labor as a uniform totality. They make no distinction, for example, for variation in region or a union's historical trajectory. Overall then, popular and academic discourse portrays union workers as economically privileged, sexist, ethnocentric, and xenophobic conservatives who enthusiastically embrace strong leaders, regardless of political orientation (Clawson 2003; Kimeldorf 1992; Lopez 2004)—worker solidarity would seem nearly impossible, much less a viable worker political movement.

Like the allegations against their employers, the issue of union economic privilege, better understood as economic empowerment, is a non-issue. Unions decisively empower their members with higher pay, benefits, and working conditions compared to their non-union counterparts (Mishel, Bernstein, and Allegretto 2007). Instead, this paper contests the assumptions about ethnocentrism and xenophobia among union US autoworkers. Examined as aspects of authoritarianism, we used a sample of union rank and file workers at a major automobile plant in a culturally conservative area of the Midwestern United States. First however, let us consider the economic-economic context of the present car wars to draw out the interconnection between the political-economy and human rights of class struggle conspicuously absent from the media coverage: healthcare, wages, and capital disinvestment.

\section{The US Auto Industry}

In the early years of the twentieth century, the US automobile industry consisted of at least 300 independent manufacturers (Gartman 1986). Transportation, politics, energy, related heavy industry, and labor all converged to provide a uniquely conducive environment for the US automobile industry in Detroit and the Great Lakes region (May 1974; Perschbacher 1996). Over the next several decades up to about 1950, the industry gradually consolidated into the Big Three (GM, Ford, and Chrysler) with smaller companies remaining such as Nash, Hudson, Packard, and Studebaker. Economic importance translated into political and cultural influence, which eventually became so great in the mid-Twentieth century that Alfred P. Sloan, co-founder of General Motors, famously declared: "What's good for General Motors is good for America" (Pelfrey 2006).

The smaller companies gradually consolidated, such as Nash and Hudson into American Motors, but eventually all except the Big Three disappeared-Studebaker failed in 1966 and Chrysler bought American Motors in 1986. Although Japanese companies had made some inroads in the 1970s, GM still controlled nearly 50\% of the US car market, and Ford and Chrysler 37\% combined (Maynard 2004). Trouble loomed, however, as Japanese per vehicle profits soared in the 1980s. Despite popular films such as Michael Moore's Roger and Me (1989), GM's relocation of factories to Mexico resulted significantly from global pressure on labor costs, energy, and resources that impacted the US auto industry for the first time in the mid-1980s, and not simply excessive profit-seeking. Yet it was not only the perceived superiority of Japanese cars that threatened the US manufacturers, but rather the respective structure 
of Japanese versus US and European industries (Heidemann 1993), namely their direct interconnection with their respective governments, which typically funded major research and development costs that created greater profit margins which were to a great extent independent of total vehicle sales. For example, the Japanese government paid $100 \%$ of the development costs for the battery and hybrid powertrain for the Toyota Prius (Kiley 2008), according to Jim Press, who worked at Toyota for 37 years and built the company's fortunes in North America.

By the late 1990s, the Big Three-by this time more commonly known as the Detroit Three-once politically dominant, lost influence rapidly during the decade due to non-US, especially Japanese success (Luger 1999). Central to this success has been Japanese monetary policy. The Japanese government invests strategically to lower the value of the Yen and thus make Japanese exports comparatively cheaper, especially for big-ticket items like cars. Data from 2006 shows that the lower yen translates into an effective subsidy on cars imported from Japan-\$9000 dollars on premium cars and $\$ 2000$ dollars on non-premium cars. Sales of cars imported from Japan increased $23 \%$ in 2006 to a total of 2.1 million vehicles, or 51\% of all Japanese cars sold in the US (Hyde 2007).

In addition to monetary manipulation, the Detroit Three carry legacy costs (health care in particular) that have far outpaced inflation. Until the new labor agreements following the 2009 bankruptcies, healthcare added $\$ 1,525$ to every vehicle GM sold, compared to only $\$ 97$ for each car Toyota built in Japan (because of national healthcare subsidies in Japan) and about $\$ 10$ in China (Hyde 2007). Price pressure prevented the Detroit Three from simply raising prices, as they have done over the last several decades (Maxton and Wormald 2004). Even Mexico has become comparatively expensive (Tuman 2002). Without a National Healthcare system, American labor will inherently be more expensive than in Japan or Germany (and more expensive still compared to the third world and Eastern Europe) even if they submit to the $401(\mathrm{k})$ retirement plan in place of a traditional guaranteed pension, as the 2008 bridge loan agreement mandates (Snavely, Merx, and Gopwani 2009). As of this writing, GM, Ford, and Chrysler are unable to pay at least 60 billion dollars combined (Saporito 2009) necessary to fund the independent UAW healthcare trust (Voluntary Employees Beneficiary Association, or VEBA) for workers, retirees, and their immediate families, as specified in the 2009 labor agreement. Consequently, Ford negotiated a replacement plan, which the union accepted, that gives the UAW equity in Ford in place of up to 50\% of Ford's VEBA obligations (Szczesny 2009). The UAW also accepted equity for debt in the GM and Chrysler bankruptcy agreements.

Such global forces threaten the middle-class standing of auto industry wage workers and therefore, the wageearning middle class, because one in every twelve jobs in the US depends directly or indirectly on GM, Ford, and Chrysler, for a total of 5,174,400 (ILIR-CAR 2004). Comparatively, all non-US car manufacturers combined contribute only 155,350 US jobs (CAR-ERG 2005). The vast difference exists because non-US companies move only assembly jobs to the US, while management, business services such as accounting and pension management, and other functions remain in the home country. The same report also finds that the domestic auto industry is responsible for nearly $20 \%$ of all capital investments in the US. While their political capital in Washington and cultural capital with the public (outside the Midwest) has diminished, their importance to the US economy remains vital. The most recent analysis predicted that the rapid termination of GM and Chrysler operations in 2009 as liquidation supporters advocated, would have immediately eliminated nearly 3 million jobs and reduced U.S. personal income nationwide by at least $\$ 150.7$ billion in the first year, and generated a total income loss of $\$ 398.2$ billion over the course of three years (Cole, McAlinden, Dziczek, and Menk 2008).

Media representation of the recent battle in Congress over the auto loans not only fails to account for the economic and cultural complexity of wage labor and capital but also systematically misdirects the public away from reality. By personalizing blame-for example by suggesting that auto company executives are arrogant and wasteful because they use corporate jets - conceals the real struggle between capital entities, in this case US versus non-US car makers. Simultaneously, it suggests that union workers are lazy and-self serving with no right to complain, and could earn a better living if they simply work harder like their non-union counterparts.

Of course, wages and benefits do not derive primarily from how hard someone works, but from capital investment or disinvestment in labor. As capital flees to lower wage and less regulated countries, they not only disinvest in the core nation, but also invest destructively in the developing world. Toyota, for example, uses coerced labor in Myanmar to produce vehicles for the Myanmar military, as well as parts for various Toyota models. The company also brings the third-world to Japan through human trafficking. Importing workers from China, southeast Asia, and Brazil, Toyota strips them of their legal documents, and forces them to work 16-hour shifts for $25 \%$ of Japanese minimum wage, or about $\$ 2.85$ / hour. After mandatory deductions for food and housing, their take-home pay is about $\$ 600.00 /$ year (see the National Labor Committee Report 2008). The London Stock Exchange recently removed Honda from the list of responsible companies for similar labor and human rights violations. Ford (and 
Volkswagen) remains in good standing (see Lundskow 2008).

\section{Union Decline and the Political-Economy of Immigrant Labor}

Union workers definitely have much to be upset about. Union labor in the United States has been in decline since the mid-1950s (Lipset and Katchanovski 2001). The downward trend accelerated greatly after 1980, as result of Ronald Reagan's reorganization of the National Labor Relations Board (Brody 1995), and even more rapidly since 2000 as George W. Bush, through a series of presidential orders (Woolley and Peters 2008), lax securities, accounting oversight, and tax incentives to encourage capital flight and US disinvestment (Galbraith 2008; Rasmus 2006). In 1980, union labor totaled 20.1 million, and declined to 15.7 million in 2005, even as total employment in the same period rose from 87. 5 million to 125.9 million (Fiorito 2007). The greatest decline in terms of union membership density has been in manufacturing, which fell from 32.3 \% in 1980 to 11.7\% in 2006 (Hirsch and Macpherson 2007). Once the center of union membership and political clout, manufacturing is now one of the least unionized sectors of the US economy.

Both political-economic and socio-cultural reasons account for this decline. Political-economic reasons include a national political shift to the right (Brody 1995; Clawson and Clawson 1999), the flight of manufacturing capital to low-wage countries (Ramrattan and Szenberg 2007; Robinson 2004) and to low-wage, non-union areas of the United States, especially the South and West (Gilpin 2001; Goodwin 2005). This coincides with a shift from manufacturing to services in general (Chandler and Jones 2003) that further eliminated union jobs. Social and cultural reasons include changes in family socialization that emphasizes individual versus collective achievement (Hester and Fuller 1999), and a change in attitude among union members from conflict to accommodation (Deery and Iverson 2005), which greatly reduced efforts to organize new facilities (Budd 2005). These forces produced a diminished and aging workforce that sought to maintain current wages and benefits until retirement (Freeman and Rogers 1999; Tetrick, Shore, McClurg, and Vandenberg 2007) rather than fight a class battle with capital (Zamudio 2004) or expand unionization, at least in the industrial sector.

Although unskilled and semi-skilled immigrant labor receives considerably lower pay than their non-immigrant counterparts (Johannsson and Weiler 2005), immigrant labor does not impact wages or benefits overall (Espenshade 1995; McCue and Norris-Tirrell 2002; Schoeni 1998) except in the lowest-level service jobs, such as custodial and physical labor (Chowdhury and Pedace 2007; Ciscel, Smith, and Mendoza 2003) where it tends to exert a slightly lowering effect. Even as the skill level of illegal immigrants improves, such as plumbers and carpenters moving into the construction industry, no significant decrease in wages has been observed as a result (Polgreen and Simpson 2006).

Rather, public policy and private employers in the form of so-called 'right to work' states exert the most control over low wages and the low-wage work experience (Haley-Lock and Shah 2007). This intersects with capital flight (Lipset and Katchanovski 2001) and lower-cost imports (Hirsch 2004; Mitchell and Erickson 2005) to depress nonunion wages (Lee 2005). Lower pay in the wage sector is thus an outcome of multiple forces: capital flight, political policy, employer policy, cheap imports, and immigrant labor-the last only in low-level service and physical labor.

Consequently, the systematic suppression of wages in unskilled and non-union employment sectors generally, and the segregation of immigrant labor specifically creates low-wage labor pools and ethnic enclaves (Clark 1998) that seldom break into higher wage sectors (Valenzuela 2007). By comparison, union labor constitutes a separate and superior wage and benefit sphere unaffected by immigrant labor and right to work laws (Mishel, et al. 2007). Although union jobs remain superior in terms of compensation, the greatly declining number of union jobs overall indicates a sharp decline in organized labor and a decline in compensation levels in the wage sector as the remaining jobsand new jobs generated by transplant facilities, e.g. Japan to the US, Northern States to the South- are increasingly non-union. It becomes clear that unionization is the only bulwark that workers have to defend themselves against predatory policy, employers, and global economic forces.

The threats to union jobs and the quality of life in the wage sector are real. Yet given overall that immigration only minimally if at all impacts union wages and benefits, the key question thus becomes both empirical and theoretical: Do union workers distinguish economic explanations from prejudicial, namely, ethnocentric explanations for declining opportunity? 


\section{Ethnocentrism and Xenophobia}

While most established unions have in fact largely ignored immigrant workers (Ness 2005), closer consideration reveals that overt racism has not been a primary factor in the last 20 years. Rather, the reutilization of union operations (Clark and Gray 2008) and local power bases with particular constituents has become increasingly important (Milkman and Voss 2004; Tait 2005). In other words, new labor pools and immigrant workers fall outside of established organizational parameters, which would require that unions allocate resources and effort to organize them. As noted above, unions have been on the defensive for decades, and typically seek to preserve current pay and benefits for current members, rather than risk declining resources on aggressive new organizational efforts.

This has contributed to stagnation in wage labor in the US, where the basic relationship of labor to capital has not changed significantly in nearly 100 years. That is, the US has and continues to maintain a two-tier working classorganized sectors (especially manufacturing) with better pay and benefits, and non-organized sectors (especially services) with low pay and minimal benefits (Fantasia and Voss 2004). If structural factors, rather than racist sentiments help to maintain union versus non-union discord, we should therefore approach the issue of immigrant labor differently. As Lavine, Lodge, and Freitas (2005) and Pedahzur and Canetti-Nisim (2004) found, for example, hostile attitudes towards outgroups during times of economic competition does not arise significantly from racist attitudes specifically, but rather, from multi-layered notions of ingroup-outgroup difference. In our context, we need a more dynamic concept than 'racism.'

Instead of racism, which denotes discrimination based on physical racial characteristics, we apply the concept of ethnocentrism, defined as "a pervasive and rigid ingroup-outgroup distinction; it involves stereotyped negative imagery and hostile attitudes regarding outgroups, stereotyped positive imagery and submissive attitudes regarding ingroups, and a hierarchical, authoritarian view of group interaction in which ingroups are rightly dominant, outgroups subordinate" (Levinson [1950] 1982: 150).

In this conceptualization, ethnocentrism refers to exaltation of one's own identity group, and xenophobia and condemnation directed at some perceived outside group. Ingroup and outgroup boundaries can be based on any number of criteria. While often based on race, ethnocentrism and xenophobia typically involve generalized and allegedly inferior qualities as embodied in particular groups of people. Thus, we study whether the autoworkers in our sample apply the ethnocentric-xenophobic ingroup versus outgroup dichotomy to immigrant and non-US labor. In substantive terms, we test for perceived 'immigrant-ness' and 'non-US-ness.' Such xenophobic notions of outgroup status allow the individual to imagine whatever they prefer as alleged indicators of essential and decisive differences, whether supposed qualities of lifestyle, temperament, values, religion, or nearly anything else. Overall, it is a measure of outsider status. We look for both ethnocentrism (exaltation of the ingroup) and xenophobia (condemnation of the outgroup).

Thus, the concept of ethnocentrism involves a particular relation of authority, that the ingroup is rightly superior and the outgroup inferior. Specifically, we examine the possibility of authoritarianism, defined as " 1 ) a high degree of submission to the established, legitimate authorities in their society; 2) high levels of aggression in the name of their authorities; and 3) a high level of conventionalism" (Altemeyer 2006: 9). At all times, the authoritarian bases submission and aggression on perceived and generalized attributes of ingroups (submission) and outgroups (aggression), and bases conventionalism on how the authoritarian believes other so-called normal people think and

behave. Both ethnocentrism and conventionality vary between individuals, but the social constant is the general stance of submission to authority, aggression toward violators, and the desire to uphold conventional attitudes.

\section{Method and Analysis}

We included modified ethnocentrism items from Zakrisson's (2005) short version of Altemeyer's (2006, 1997) RWA (Right-Wing Authoritarianism) scale, as well as our own questions about employment, for a total of nine questions. All of them use a seven-point Likert scale (table 1). 
Table 1: Survey Items

\begin{tabular}{|l|l|l|}
\hline Economic Awareness & Ethocentrism & Reversals \\
\hline $\begin{array}{l}\text { 1. Competition from non-US compa- } \\
\text { nies is the biggest threat to American } \\
\text { workers. }\end{array}$ & $\begin{array}{l}\text { 1. If my union seeks support from } \\
\text { outside groups, it will become weak } \\
\text { and ineffective. }\end{array}$ & $\begin{array}{l}\text { 1. There is no ONE right way to live. } \\
\text { Many different ways of life are OK. }\end{array}$ \\
\hline $\begin{array}{l}\text { 2. In today's world, jobs leave the Unit- } \\
\text { ed States no matter what unions do. }\end{array}$ & $\begin{array}{l}\text { 2. What our country needs most is a } \\
\text { powerful leader who will use force to } \\
\text { wipe out our problems. }\end{array}$ & $\begin{array}{l}\text { 2. We should always be open to new } \\
\text { ideas, because they are the lifeblood of } \\
\text { a free and democratic society. }\end{array}$ \\
\hline $\begin{array}{l}\text { 3. Union labor will not survive unless it } \\
\text { gives the company an advantage over } \\
\text { non-union labor. }\end{array}$ & $\begin{array}{l}\text { 3. What our country really needs, } \\
\text { instead of more "civil rights," is a good } \\
\text { stiff dose of law and order. }\end{array}$ & $\begin{array}{l}\text { 4. American workers would be doing } \\
\text { fine if there weren't so many illegal } \\
\text { immigrants. }\end{array}$ \\
\hline & \\
\hline
\end{tabular}

All 1,040 workers at a US Midwestern automobile fabrication plant received a survey in June 2007, distributed by United Auto Workers (UAW) union officials. A total of 261 surveys were collected and used in the study, for a response rate of $25 \%$. Due to the relatively low response rate, values in the under-represented categories of 'female' and 'non-white' where weighted to match known demographics of this plant.

The survey included several different sections. Relevant to this paper, workers were asked nine questions which were intended to measure economic awareness and ethnocentrism. Two questions were reversals of ethnocentrism. We compared the outcomes on the ethnocentrism and economic awareness questions with key demographic variables: age, race, and gender. The reversals indicate an active anti-ethnocentric orientation. In other words, a person who agrees or strongly agrees with the reversals demonstrates an open and tolerant (anti-ethnocentric) orientation.

\section{Age}

Age has a range of 39 with a minimum age of 31 and a maximum age of 70 . The mean age of all workers surveyed is 50.32 years, and the median is 50 (figure 1). Thus, we have a relatively older worker population, which is not surprising since this plant, like most plants among the domestic auto industry, has not hired workers from outside the company since the mid-1980s.

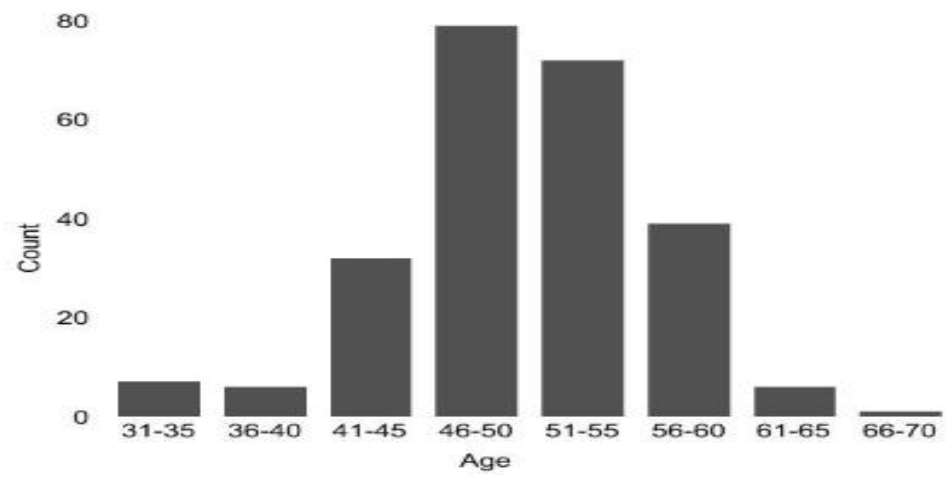

Figure 1: Workers' Age Distribution

With age as the independent variable, only two items are significant at the .05 level or better. Regarding the issue of "USA needs a powerful leader," we see only a weak positive correlation, meaning that increasing age slightly predicts greater support for this attitude. The second item, “jobs will leave the USA no matter what unions do," is also a weak positive relationship (table 2 ). 
Table 2: Significance and R-Values for Age

\begin{tabular}{|l|l|l|l|}
\hline Variable & P-value & R & R-squared \\
\hline Non-US competition is biggest threat to US jobs & .934 & 0.13 & .000 \\
\hline Outside support weakens the union & .355 & .086 & .007 \\
\hline USA needs a powerful leader & .012 & .161 & .026 \\
\hline There is no one right way to live & .974 & .009 & .000 \\
\hline U.S.A. needs more law and order & .428 & .077 & .006 \\
\hline Illegal immigrants hurt American workers & .546 & .010 & .000 \\
\hline New ideas are important & .929 & .019 & .000 \\
\hline Jobs leave USA no matter what unions do & .002 & .166 & .028 \\
\hline Union needs to give an advantage over non-union labor & .103 & .121 & .015 \\
\hline
\end{tabular}

\section{Gender}

With gender, we have three significant outcomes at the .05 level or better.

Table 3: Gender Wilcoxon Rank Sum

\begin{tabular}{|l|l|l|}
\hline Variable & Statistic & P-value \\
\hline Non-US competition is the biggest threat to US jobs & 4727.0 & .060 \\
\hline Outside support weakens union & 4427.0 & .029 \\
\hline USA needs powerful leader & 4283.0 & .012 \\
\hline No one right way to live & 4440.0 & .014 \\
\hline USA needs more law and order & 23535.0 & .301 \\
\hline Illegal immigrants hurt American workers & 4860.0 & .111 \\
\hline New ideas important & 23860.5 & .618 \\
\hline Jobs leave USA no matter what & 24332.0 & .913 \\
\hline Union needs to give advantage & 4767.5 & .226 \\
\hline
\end{tabular}

Concerning outside support for the union, men more strongly believe that outside support weakens the union, while women are almost uniformly distributed on this question (figure 2).

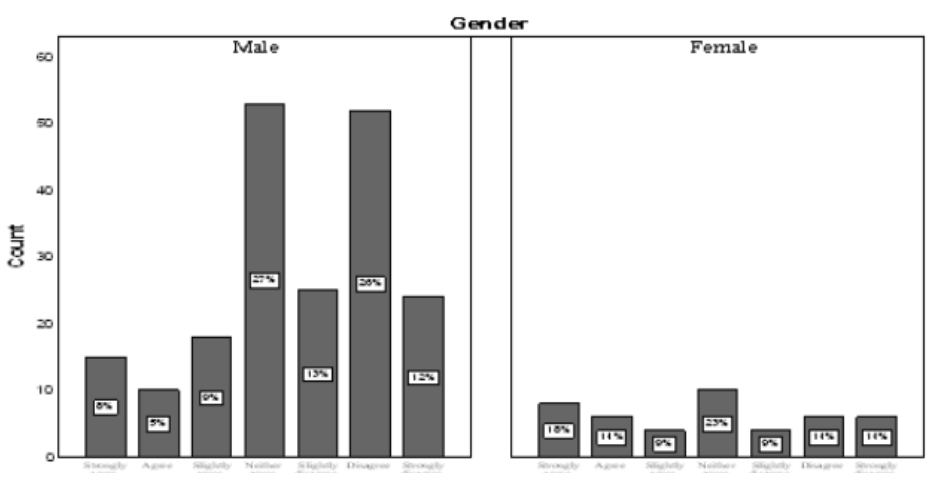

Figure 2: Gender and Outside Support for the Union 
This suggests that men take a more stand-alone attitude than women, although the single largest response category for men was "neither agree nor disagree." A large number of men regard this issue with either ambivalence, or as a non-issue to which they give little consideration.

Regarding authoritarian leadership, we see fairly even distribution for both men and women, with women favoring a strong leader more consistently than men. The mode response for women was "strongly agree," compared to men, for whom the largest number favored "disagree" (figure 3).

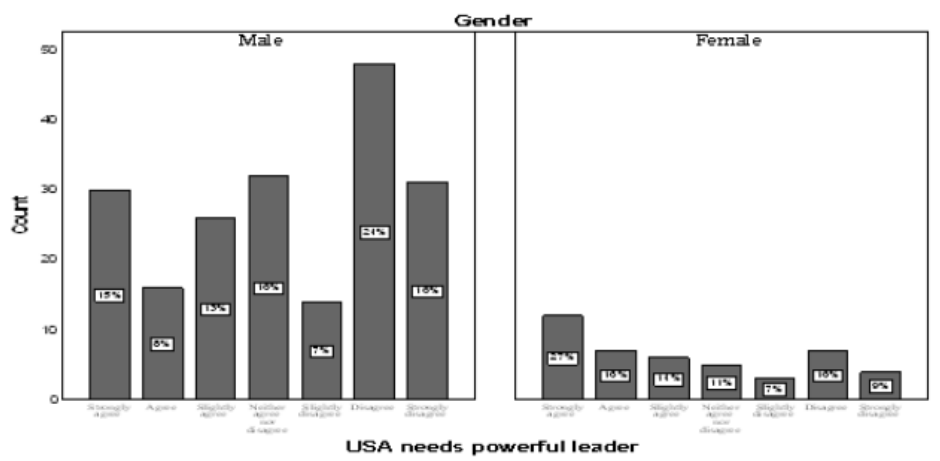

Figure 3: Gender and Authoritarian Leadership

Although 57\% of women favor a powerful leader to some extent, their commitment is still lukewarm, with as many choosing "disagree" as "agree." Men generally oppose the idea of a strong national leader, with a fair number $(16 \%)$ in the middle.

Both men and women are more decisive regarding lifestyles, in agreement that there is no one right way to live. Although we cannot discern from this study exactly which lifestyles in particular they might accept or reject, the results do show a general open-mindedness (figure 4).

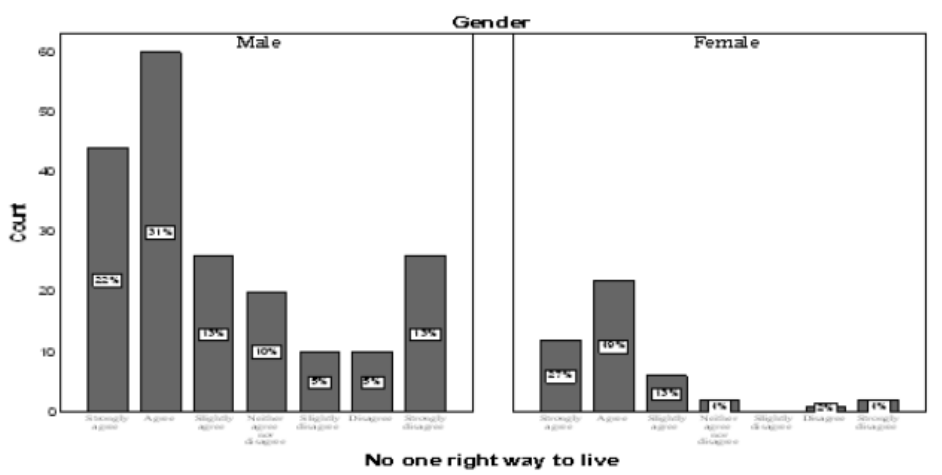

Figure 4: Gender and Lifestyle 


\section{Race}

With race as the independent variable, we have one significant outcome, that non-US competition is the biggest threat to US jobs.

Table 4: Race Wilcoxon Rank Sum

\begin{tabular}{|l|l|l|}
\hline Variable & Statistics & P-value \\
\hline Non-US competition is biggest threat & 3889.5 & .050 \\
\hline Outside support weakens union & 4203.0 & .310 \\
\hline USA needs powerful leader & 3976.5 & .117 \\
\hline No one right way to live & 4443.0 & .993 \\
\hline USA needs more law and order & 21290.5 & .701 \\
\hline Illegal immigrants hurt American workers & 4621.0 & .960 \\
\hline New ideas important & 3891.5 & .093 \\
\hline Jobs leave USA no matter what & 4158.5 & .346 \\
\hline Union needs to give advantage & 4445.0 & .956 \\
\hline
\end{tabular}

In this case, attitudes are decisive. For both white and non-white, the workers overwhelmingly believe that nonUS competition is the biggest threat to US jobs. This mirrors the results with age, and demonstrates a degree of consistency in worker attitudes (figure 5).

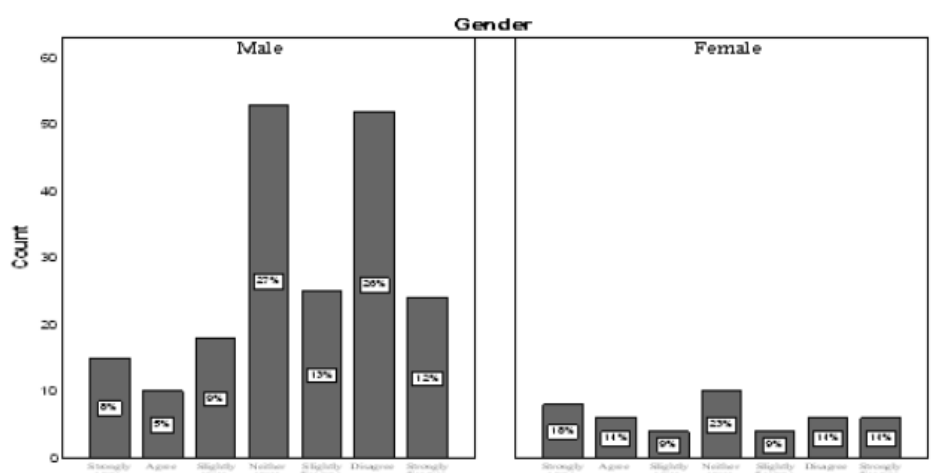

Figure 5: Race and Perception of Competition

Although non-whites are more decisive than whites, both clearly see non-US competition as the biggest threat to US jobs.

\section{Survey Conclusions}

Overall, the results show that the workers do not blame immigrant labor for the decline of established labor, and they do not favor strong, i.e. authoritarian leaders. Although they do see threats to US jobs, which the discussion above shows are real, they understand these threats mainly in economic terms, not in emotional or personal terms. In other words, they understand their world as the interaction of social forces that cannot be corrected by blaming outgroups (such as immigrant labor) nor by embracing authoritarian leaders.

The fact that the notion of 'competition from non-US companies' is statistically significant, and the fact that attitudes that blame immigrant workers are not significant is important. It suggests that workers differentiate non-US 
people from non-US business. They see business competition as an issue separate and distinct from non-US workers, including non-US workers who come to the US as illegal immigrants. The workers in our study do not see them as a threat. In short, the workers favor economic explanations rather than ethnocentric explanations for the decline of jobs, pay, and benefits. Similarly, the workers reject a call for a strong leader. They see job loss as an outcome of social forces that cannot be improved with ethnocentric exclusion championed by a strong leader.

We hesitate to draw more detailed or elaborate conclusions, but we believe that these preliminary results warrant much closer investigation with larger samples and drawn from several additional plants. Attitudes among workers in the automobile industry may not represent industrial workers generally, as the auto industry is decisively global, and this fact is readily apparent to workers in our study, who are fully aware (from other parts of the survey) that raw materials and parts come from all over the world. This uncertainty about industrial workers in general only points to the need for a fresh look at US industrial labor.

Specifically, the various measures of authoritarianism have advanced considerably over the past several decades, but have been applied little to labor studies. Now refined as both short forms (e.g. Duckitt and Fisher 2002; Feldman 2003; Rattazi, Bobbio, and Canova 2007; Zakrisson 2006) and long forms (e.g. Altemeyer 2006; Ekehammar, Akrami, Gylje, and Zakrisson 2004), the various authoritarian scales offer considerable potential for new insight. Similarly, authoritarianism (conventionalism, submission, and aggression) examines the role of dominance, ethnocentrism and prejudice between groups. If further applied in conjunction with Social Dominator measures (e.g. Sidanius and Pratto 1999), which looks at dominance and aggression within groups, the resultant multi-concept approach would offer new, accurate, and detailed findings on attitudes, identity, and worldview (Heaven and St. Quintin 2003; Peterson, Duncan, and Pang 2002).

\section{The Possibility of Worker Solidarity}

The workers in our study are much more aware of global economic realties and are more open-minded than commonly perceived. Given that the workers in our study are not hostile in their attitudes towards illegal immigrants, this suggests important political ramifications and a more assertive working class-if the industrial unions and the UAW in particular can organize non-US plants, which stand in culturally conservative areas that are traditionally hostile to unionization and where right-to-work laws inherently undermine collective bargaining.

At present however, our union auto workers are not much concerned about issues beyond those relevant to their own employment and retirement—-most likely because most are nearing the end of their working life, even as young workers rediscover the benefits of unionization (Goldstein 2008). Our case of relatively high level of awareness in the absence of significant union commitment parallels other established industrial unions (Hammer and Avgar 2005) and follows a documented pattern as unions age (McCall 2008) that produces ambivalent workers who at once understand the economic power (i.e. class) relations of their employment, but earn sufficient compensation and are sufficiently close to retirement to neutralize active union involvement in the face of declining union strength. This resultant lack of enthusiasm among workers negates a sense of purpose or empowerment and heightens ambivalence (Twigg, Fuller, and Hester 2008).

A preponderance of ambivalence points to the need for more intensive study of middle-scorers on all the various surveys that measure attitudes, personality, opinions, as well as union commitment, involvement, and satisfaction. Since the majority of workers almost always score in the middle on such surveys, Smith and Hanley (2007) correctly argue that the middle-scorers — that is, the ambivalent middle of the US population — has received very little attention in favor of the high and low scorers. Quite simply, middle-scorers are the ones who can go either way. All it takes is the right campaign to sway them left or right, the right public relations scheme to sway them for or against this or that initiative, the right trend to support or oppose this or that policy. As Robert Hamilton (1982) showed, it didn't take a nation to elevate Hitler to power, only about $10 \%$ ardent supporters and another $22 \%$ who saw certain opportunities in Nazism, and the rest of the population — the ambivalent middle—who failed to oppose him.

These findings also suggest important ramifications for politics and economics in the United States, such as the possibility of new political alignments premised on class rather than cultural identity, race, or xenophobia. Resistance to unionization has strong cultural roots in the South (Clark, Delaney, and Frost 2002; Fantasia and Voss 2004) as well as increasing policy and legal restrictions (Whitford 2005), but our results suggest the possibility, far from any certainty, that class could unite otherwise monolithic organized labor, disparate ethnic labor enclaves, and 
culturally fearful Southern workers. Unionization would be the vehicle for creating such unity, but it will require the mobilization of existing unions to organize all sectors of labor. It will also require alliances, most of which have not been explored as yet, for example alliances between industrial labor and environmental and civil-rights groups. One notable exception would be the alliance between the Oil, Chemical, and Atomic Workers Union (OCAW) with the Sierra Club and other environmental organizations since the 1980s.

Any resistance to capital domination must build such alliances, both domestically and globally. As companies globalize, so must labor. For example, when Daimler-Chrysler decided to sell the Chrysler division in 2006, it provoked German workers to stand in solidarity with their US counterparts-German workers threatened to strike if Daimler sold Chrysler to a party that would dismantle the company (Tierney and Vlasic 2007). Our study suggests that workers are open to new alliances, that potential friends come in diverse colors, origins, lifestyles, and beliefs, but this also requires politization in a particular orientation, that the struggle against capital transcends local, regional, national, and ethnic interests and prejudices.

\section{Endnotes}

1. Overall comparisons are somewhat problematic, given that the productivity leader, Toyota, produces only non-premium vehicles in North America-the Lexus premium line is produced in Japan. In contrast, GM, Ford, and Chrysler produce premium vehicles in North America as well, which inherently require more labor time in all phases. Consider, for example, that the supercharged V-8 engine for the Cadillac CTS-V is assembled entirely by hand. While Toyota produces an equivalent hand-made engine, the new V-8 for the Lexus IS-F, this engine is made only in Japan, by union workers. Thus, if we compare only non-premium plants in North America, Toyota's non-union labor is fourth, behind the union labor of GM, Chrysler, and Ford, in that order.
George N. Lundskow and Brian Phillips are associate professors of sociology.

Phyllis Curtiss is associate professor of statistics.

Katherine Rehorst and Allison M. Wehr are undergraduate research assistants.

Address all correspondence to: George N. Lundskow, Department of Sociology, 2170 AuSable Hall, Grand Valley State University, Allendale, MI 49401. Ph: 616331-3704. Fax: 616-331-3735. E-Mail: Lundskog@ gvsu.edu.

\section{References}

Altemeyer, Bob. 2006. The Authoritarians. Winnipeg, Canada: University of Manitoba Press.

Altemeyer, Bob. 1997. The Authoritarian Spectre. Cambridge, MA: Harvard Univesity Press.

AP Interactive. 2008. "Detroit's Big Three: A Look at the American Automakers.” http://hosted.ap.org/dynamic/files/ specials/interactives/_business/big_three/index.html, accessed January 2, 2008.

Apostolidis, Paul. 2005. "Hegemony And Hamburger: Migration Narratives And Democratic Unionism Among Mexican Meatpackers In The U.S. West." Political Science Quarterly 58: 647-658.

Aronowitz, Stanley. 1998. From The Ashes Of The Old: American Labor And America’s Future. New York: Houghton-Mifflin.
Battista, Andrew. 2008. The Revival Of Labor Liberalism. Champaign-Urbana, IL: University of Illinois Press.

Brody, David. 1995. "Criminalizing The Rights Of Labor." Dissent 42: 363-367.

Budd, John W. 2005. Labor Relations: Striking A Balance. New York: McGraw-Hill.

CAR-ERG Report. 2005. "Contribution of the International Auto Sector to the US Economy, An Update." Ann Arbor: Center for Automotive Research and Economics Research Group.

Chandler, Susan and Jill Jones. 2003. "Because A Better World Is Possible: Women Casino Workers, Union Activism, And The Creation Of A Just Workplace." Journal of Sociology and Social Welfare 30: 57-78. 
Chang, Tracy F.H. 2003. "A Structural Model Of Race, Gender, Class, And Attitudes Towards Labor Unions." The Social Science Journal 40: 189-200.

Ciscel, David H., Barbara Ellen Smith, and Marcela Mendoza. 2003. "Ghosts In The Machine: New Immigrants And The Redefinition Of Work." Journal of Economic Issues 37: 333-341.

Clark, William A.V. 1998. "Mass Migration And Local Outcomes: Is International Migration To The United States Creating A New Urban Under Class?” Urban Studies 35: 371-383.

Clark, Paul F. and Lois S. Gray. 2008. "Administrative Practices in American Unions: A Longitudinal Study." Journal of Labor Research 29: 42-55.

Clark, Paul F., John Thomas Delaney, and Ann C. Frost. 2002. Collective Bargaining in the Private Sector (Industrial Relations Research Association Series). Champaign-Urbana, IL: University of Illinois Press.

Clawson, Dan. 2003. The Next Upsurge: Labor and the New Social Movements. Ithaca, NY: Cornell University Press.

Clawson, Dan, and Mary Ann Clawson. 1999. "What Has Happened To The US Labor Movement? Union Decline And Renewal." Annual Review of Sociology 25: 95-119.

Cole, David, Sean McAlinden, Kristin Dziczek, and Debra Maranger Menk. 2008. CAR Research Memorandum: The Impact on the U.S. Economy of a Major Contraction of the Detroit Three Automakers. Ann Arbor, MI: Center for Automotive Research.

Deery, Stephen J., and Roderick D. Iverson. 2005. "LaborManagement Cooperation: Antecedents And Impact On Organizational Performance." Industrial and Labor Relations Review 58: 588-609.

Dubofsky, Melvyn. 2000. Hard Work: The Making of American Labor History. Champaign-Urbana, IL: University of Illinois Press.

Duckitt, John and Kirstin Fisher. 2003. "The Impact Of Social Threat On Worldview And Ideological Attitudes.” Political Psychology 24: 199-222.

Editors of Consumer Reports. 2008. New Car Buying Guide, 2008. Yonkers, NY: Consumer Reports.

Ekehammar, Bo, Nazar Akrami, Magnus Gylje, and Ingrid Zakrisson. 2004. "What Matters Most To Prejudice: Basic Personality, Social Dominance Orientation Or Right-Wing Authoritarianism?" European Journal of Personality 18: 463-482.

Espenshade, Thomas J. 1995. "Unauthorized Immigration to the United States.” Annual Review of Sociology 21: 195-216.

Fantasia, Rick, and Kim Voss. 2004. Hardwork: Remaking The American Labor Movement. Berkeley: University of California Press.

Feldman, Stanley. 2003. "Enforcing Social Conformity: A Theory Of Authoritarianism." Political Psychology, 24: 41-74.
Fiorito, Jack. 2007. "The State Of Unions In The United States." Journal of Labor Research 28: 43-68.

Fiorito, Jack, Daniel G. Gallagher, and Cynthia V. Fukami. 1988. "Satisfaction With Union Representation." Industrial Labor Relations Review 41: 294-307.

Francia, Peter L. 2006. The Future Of Organized Labor In American Politics. New York: Columbia University Press.

Galbraith, James. 2008. The Predator State: How Conservatives Abandoned the Free Market and Why Liberals Should Too. New York: The Free Press.

Gartman, David. 1986. Auto Slavery: The Labor Process in the American Automobile Industry, 1897-1950. New Brunswick, NJ: Rutgers University Press.

Gilpin, Robert. 2001. Global Political Economy: Understanding The International Economic Order. Princeton, NJ: Princeton University Press.

Goldstein, Dana. 2008. "Another Kind Of Youth Movement: A New Generation Discovers An Old Idea-Trade Unionism.” The American Prospect, March: A16.

Goodwin, Neva. 2005. “The Social Impact Of Multinational Corporations: An Outline Of The Issues With A Focus On Workers." Leviathans: Multinational Corporations and the New Global History, ed. Alfred D. Chandler and Bruce Mazlish. New York: Cambridge University Press.

Harbour Report, North America. 2008. New York: Oliver Wyman Company.

Heaven, Patrick C.L. and David St. Quintin, D. 2003. "Personality Factors Predict Racial Prejudice." Personality and Individual Differences 34: 625-634.

Haley-Lock, Anna, and Melissa Ford Smith. 2007. "Protecting Vulnerable Workers: How Public Policy And Private Employers Shape The Contemporary Low-Wage Work Experience." Families in Society: The Journal of Contemporary Social Services 88: 485-495.

Hammer, Tove Helland and Ariel Avgar. 2005. "The Impact Of Unions On Job Satisfaction, Organizational Commitment, And Turnover." Journal of Labor Research 26: 241-266.

Heidemann, Winfried. 1994. Qualification in the Automobile Industry: The Reaction of European Companies to the Japanese Lean Production System. Düsseldorf: Hans Bockler Stiftung.

Hester, Kim and J. Bryan Fuller. 1999. "An Extension Of The Family Socialization Model Of Union Attitudes.” The Journal of Social Psychology 139: 396-398.

Hirsch, Barry T. 2004. "What Do Unions Do For Economic Performance?” Journal of Labor Research 25: 415-455.

Hirsch, Barry T., and David Macpherson. 2007. "U.S. Historical Tables: Union Membership, Coverage, Density And Employment, 1973-2006." www.trinity.edu/bhirsch/ unionstats/. 
Honda Press Release. 2009. "American Honda Reports February Sales." American Honda Motor Company, Torrance, CA, March 3.

Hyde, Justin. 2007. "Dollar vs Yen: Impact on Auto Proces and Profits." Detroit Free Press, February 25.

Hyde, Justin, and Tim Higgins. 2009. "UAW Strike Would Kill Auto Loans: Auto Rescue Terms Raise Stakes In Deal Mandating Changes In Pay, Benefits." Detroit Free Press, January 9.

Iliffe-Moon, Sona, and Zoe Zeigler. 2009. “Toyota Reports February Sales.” Toyota USA Newsroom, Torrance, CA, March 3.

ILIR-CAR Report. 2004. "Contribution Of The U.S. Motor Vehicle Industry To The Economies Of The United States, California, New York, And New Jersey In 2003." Ann Arbor: Institute of Labor and Industrial Relations and the Center for Automotive Research.

Johannsson, Hannes, and Stephen Weiler. 2005. "Immigration And Wage Inequality In The 1990s: Panel Evidence From The Current Population Survey." The Social Science Journal 42: 231-240.

Karesh, Michael. 2007. "Seven Serious Problems with Consumer Reports.” True Delta, http://www.truedelta.com/pieces/shortcomings.php?session_code=, accessed January 2, 2009.

-----. 2006. "Change but not for the Better: Consumer Reports New Ratings." True Delta, http://www.truedelta.com/pieces/ newdots.php, accessed January 2, 2009.

Kiley, David. 2008. “The Road To A Stronger CAFE Standard: U.S. Automakers Have To Get Toiling To Meet New FuelEfficiency Legislation." BusinessWeek, March 25.

Kimeldorf, Howard. 1992. Reds or Rackets? The Making of Radical and Conservative Unions on the Waterfront. Berkeley: University of California Press.

Lavine, Howard, Milton Lodge, and Kate Freitas. 2005. "Threat, Authoritarianism, And Selective Exposure To Information.” Political Psychology 26: 219-244.

Lee, Cheol-Sung. 2005. "International Migration, Deindustrialization And Union Decline In 16 Affluent OECD Countries, 1962-1997." Social Forces 84: 71-88.

Levinson, Daniel J. [1950] 1982. The Authoritarian Personality. New York: W.W. Norton.

Lichtenstein, Nelson. 2002. State Of The Union: A Century Of American Labor. Princeton, NJ: Princeton University Press.

Lipset, Seymour Martin, and Ivan Katchanovski. 2001. "The Future Of Private Sector Unions In The U.S.” Journal of Labor Research 22: 229-244.

Loewen, James W. 2007. "Patriotism, Nationalism, And Our Jobs As Americans.” Pledging Allegiance: The Politics of Patriotism in American Schools, ed. Joel Westheimer. New York: Columbia University Press.
Lopez, Stephen Henry. 2004. Reorganizing the Rust Belt: An Inside Study of the American Labor Movement. Berkeley and Los Angeles: University of California Press.

Luger, Stan. 1999. Corporate Power, American Democracy, and the Automobile Industry. New York: Cambridge University Press.

Lundskow, George. 2008. “Toyota's Willing Stooges: The Trend of Narcissism in US Society." New York Journal of Sociology 1: 91-116.

Lüthje, Boy and Christoph Scherrer. 2001. "Race, Multiculturalism, And Labor Organizing In The United States: Lessons For Europe.” Capital and Class 73: 141-171.

McCall, Phil. 2008. "We Had to Stick Together: Individual Preferences, Collective Struggle, and the Formation of Social Consciousness. Science and Society 72: 147-181.

McCue, Clifford P., and Dorothy Norris-Tirrell. 2002. "The Impact Of Immigration Policy On Communities: An Introduction To The Symposium." Policy Studies Journal 30: 53-57.

May, George S. 1974. A Most Unique Machine: The Michigan Origins of the American Automobile Industry. Grand Rapids: William B. Eerdemans.

Maynard, Micheline. 2008. "UAW At Center Of Dispute Over Bailout.” New York Times, December 12.

Maxton, Graeme P. and John Wormald. 2004. Time for a Model Change: Re-engineering the Global Automotive Industry. New York: Cambridge University Press.

Maynard, Micheline. 2004. The End of Detroit: How the Big Three Lost Their Grip on the American Car Market. New York: Currency/Doubleday.

Merx, Katie. 2008. "Strings On Auto Loans Risky For Retirees: Stocks Would Be Used For Half Of Health-Care Trust." Detroit Free Press, December 25.

Morici, Peter. 2008. “No Foolin', Obama Must Get Auto Unions To Do Their Part.” Detroit Free Press, December 23.

Milkman, Ruth and Kim Voss. 2004. Rebuilding Labor: Organizing And Organizers In The New Union Movement. Ithaca, NY: Cornell University Press.

Mishel, Lawrence, Jared Bernstein, and Sylvia Allegretto. 2007. The State Of Working America, 2006/2007. Ithaca, NY: Cornell University Press.

Mitchell, Daniel J.B. and Christopher L. Erickson. 2005. "DeUnionization And Macro Performance: What Freeman And Medoff Didn't Do." Journal of Labor Research 26, Spring: 183-208.

Mussadeq, Chowdhury, and Roberto Pedace. 2006. "Ethnic Enclaves And Labor Markets: An Analysis Of Immigrant Outcomes In California." Contemporary Economic Policy 25: 238-249. 
National Labor Committee Report. 2008. “The Toyota You Don't Know: The Race to the Bottom in the Auto Industry." New York: National Labor Committee.

Ness, Immanuel. 2005. Immigrants, Unions, And The New US Labor Market. Philadelphia: Temple University Press.

Pedahzur, Ami and Daphna Canetti-Nisim. 2004. "Support For Right-Wing Extremist Ideology: Socio-Economic Indicators And Socio-Psychological Mechanisms Of Social Identification." Comparative Sociology 3: 1-36.

Pelfrey, William. 2006. Billy, Alfred, and General Motors: The Story of Two Unique Men, A Legendary Company, and a Remarkable Time in American History. New York: American Management Association.

Perschbacher, Gerald. 1996. Wheels in Motion: The American Automobile Industry's First Century. Iola, Wisconsin: Krause Publications.

Peterson, Bill. E., Lauren E. Duncan, and Joyce S. Pang. 2002. "Authoritarianism And Political Impoverishment: Deficits In Knowledge And Civic Disinterest." Political Psychology 23: 97-112.

Polgreen, Linnea, and Nicole B. Simpson. 2006. "Recent Trends In The Skill Composition Of Legal U.S. Immigrants.” Southern Economic Journal 72: 938-957.

Preston, Valerie, S. McLafferty, and X.F. Liu. 1998. "Geographical Barriers To Employment For American-Born And Immigrant Workers." Urban Studies 35: 529-545.

Rasmus, Jack. 2006. The War at Home: The Corporate Offensive from Ronald Reagan to George W. Bush. San Ramon, CA: Kyklos Productions.

Rattazzi, Anna Maria Manganelli, Andrea Bobbio, and Luigina Canova. 2007. "A Short Version Of The Right-Wing Authoritarianism Scale." Personality and Individual Differences 43: 1223-1234.

Robinson, William I. 2004. A Theory Of Global Capitalism: Production, Class, And State In A Transnational World. Baltimore, MD: John Hopkins University Press.

Ramrattan, Lall, and Michael Szenberg. 2007. Distressed US Industries In The Era Of Globalization. Burlington, VT: Ashgate Publishing.

Saporito, Bill. 2009. "The UAW Fights Its Image As The Villian Of Detroit." Time Magazine, March 1, www.time.com/time/ business/article/0,8599,1882376,00.html.

Schoeni, Robert F. 1998. "Labor Market Assimilation Of Women." Industrial and Labor Relations Review 51: 483-504.

Smith, David. and Hanley, Eric. 2007. "New Frontiers in the Study of Authoritarianism" Paper presented at the annual meeting of the International Society of Political Psychology, Classical Chinese Garden, Portland, Oregon USA, Jul 04, 2007. 200812-11 http://www.allacademic.com/meta/p204763_index. html
Snavely, Brent. 2009. "Detroit 3 Look For Midyear Sales Boost In Stimulus Aid: Market Likely To Stay Rough For At Least First Half Of Year." Detroit Free Press, January 9.

Snavely, Brent, Katie Merx, and Jewel Gopwani. 2009. "UAW In Detroit Today For Contract Talks In Wake Of Automaker Loans." Detroit Free Press, January 9.

Snell, Robert. 2009. “GM Lawyer Urges Judge To Approve Asset Sale.” Detroit News, July 2.

Spangler, Todd. 2008. Shelby Criticizes Bush, Rescue Plan. Detroit Free Press, December 19.

Szczesny, Joseph R. 2009. "UAW Cuts Healthcare Deal With Ford." Time Magazine, February 23, www.time.com/time/ business/article/0,8599,1881377,00.html.

Tait, Vanessa. 2005. Poor Workers' Unions: Rebuilding Labor From Below. Boston: South End Press.

Tetrick, Lois E., Lynn M. Shore, Lucy Newton McClurg, and Robert J. Vandenberg. 2007. "A Model Of Union Participation: The Impact Of Perceived Union Support, Union Instrumentality, And Union Loyalty." Journal of Applied Psychology: 820-828.

Tierney, Christine, and Bill Vlasic. 2007. "DCX Unions Open to Magna." Detroit News, April 25.

Tierney, Christine, Robert Snell, and Bryce G. Hoffman. 2009. "Auto Sales Skid: Recovery Rests on Stimulus." Detroit News, January 6.

Tuman, J.P. 2002. Reshaping the North American Automobile Industry: Restructuring, Corporatism and Union Democracy in Mexico (Employment and Work Relations in Context Series). New York: Routledge.

Twigg, Nicholas W, J. Brian Fuller, and Kim Hester. 2008. "Transformational Leadership in Labor Organizations: The Effects on Union Citizenship Behaviors." Journal of Labor Research, 29: 27-41.

Valenzuela, Abel. 2007. "Immigrant Day Laborers: Myths And Realities.” NACLA Report on the Americas 40: 25-29, 41.

Walsh, Tom. 2009. “When Toyota's Begging It Bad.” Detroit Free Press, March 4.

Whitford, Josh. 2005. The New Old Economy: Networks, Institutions, and the Organizational Transformation of American Manufacturing. New York: Oxford University Press.

Woolley, John T. and Gerhard Peters. 2008. The American Presidency Project. Santa Barbara, CA: University of California Press.

Zakrisson, Ingrid. 2005. "Construction Of A Short Version Of The Right-Wing Authoritarianism (RWA) Scale." Personality and Individual Differences 39: 863-872.

Zamudio, Margaret. 2004. "Alienation And Resistance: New Possibilities Of Working-Class Formation.” Social Justice 31, 3: 60-76. 